\title{
Effect of public spending on agricultural productivity in Nigeria (1981-2018)
}

\author{
Temidayo Apata*
}

Federal University Oye-Ekiti, Department of Agricultural Economics and Extension, Ikole Campus, Ikole, P.M.B. 374101, Ekiti Satate, Nigeria

Received: 15 May 2020 / Accepted: 1 October 2020

\begin{abstract}
This study examines the effect of public spending on agricultural productivity in major agro-ecological regions in Nigeria (19812018). Using public finance data from agricultural and the non-agricultural sectors at a national level, agricultural productivity returns were analysed. Public spending on drivers of agricultural growth such as education, farm feeder roads and health care facilities and their effect on agricultural productivity were also examined. Data were analysed using descriptive statistics and three-stage simultaneous equations. Descriptive statistics analysis results indicated that agricultural public spending as a part of total public spending averaged $4.88 \%$ between 1981 and 2018 across zones in Nigeria. Less than 25\% of this allocation was spent on agricultural developmental/capital project. Elasticity results computed from the 3-stage simultaneous equation showed that the access to moderate farm feeder roads variable was 0.045 , the access to education variable was 0.071 and the access to health care facilities (within 15-30 minutes' walk to health facility) variable was 0.013 . These variables were all significant at $1 \%$. Such outcomes suggest that a $1 \%$ increase in the funding of education, farm feeder roads and health care facilities will enhance agricultural productivity per capita by 0.043 . Hence, the results revealed an estimated benefit-cost-ratio of 4.3:1. Consequently, public expenditure on education, farm feeder roads and health care facilities of $4.3 \%$ would enhance agricultural productivity by $1 \%$. However, the assessed marginal consequences and returns vary for four agro-ecological regions. Hence, harmonizing along with quality public spending on access to health care facilities, education and farm feeder roads would enhance agricultural productivity.
\end{abstract}

\section{Keywords}

Public expenditure and financings/ Marginal returns / Agricultural output / Agro-ecological zones / Nigeria.

\section{0 efecto do gasto público na produtividade agrícola en Nixeria (1981-2018)}

\section{Resumo}

Este estudo examina o efecto do gasto público na produtividade agrícola nas principais rexións agroecolóxicas de Nixeria (1981-2018). Utilizando datos das finanzas públicas nacionais procedentes tanto dos sectores agrícola coma non agrícola, analízanse os rendementos da produtividade agrícola. Tamén se estuda o gasto público nos motores do crecemento agrícola como a educación, as vías de acceso ás granxas e as instalacións de atención médica, e mais o seu efecto sobre a produtividade. Os datos analizáronse mediante estatística descritiva e ecuación simultánea en tres etapas. Os resultados da análise estatística indicaron que o gasto público agrícola, como parte do gasto público total, foi do 4,88\% de media entre 1981 e 2018 en todas as zonas de Nixeria. Menos do 25\% desta asignación foi empregado en proxectos de capital/desenvolvemento agrícola. Os resultados de elasticidade calculados a partir da ecuación simultánea de tres etapas mostraron que a variable vías de acceso ás granxas foi de 0,045, á educación de 0,071 e ás instalacións de atención médica (a 15-30 minutos camiñando ao centro de saúde) de 0,013 . Todas estas variables resultaron significativas ao $1 \%$. Estes resultados suxiren que un aumento do $1 \%$ no financiamento na educación, nas vías de acceso ás granxas e nas instalacións de atención médica melloraría a produtividade agrícola per cápita un 0,043 . Polo tanto, os resultados revelaron unha relación custo-beneficio de 4,3:1. En consecuencia, un gasto público en educación, nas vías de acceso ás granxas e nas instalacións de atención médica dun 4,3\% melloraría a produtividade agrícola nun $1 \%$. Porén, as consecuencias marxinais avaliadas e mais os retornos varían nas catro rexións agroecolóxicas. Xa que logo, harmonizar un gasto público de calidade nas instalacións de atención médica, na educación e nas vías de acceso ás granxas mellorará a produtividade agrícola.

\section{Palabras clave}

Gasto público e financiamento / Rendibilidade marxinal / Produción agrícola / Zonas agroecolóxicas / Nixeria.

JEL Codes: Q10.

* Corresponding author: dayo.apata@fuoye.edu.ng 


\section{Introduction}

Public spending/expenditure is the basis of budget building and an expectation for development for today and, also, for the future. During the scope years (1981-2018) sustainable public spending in Nigeria has been a debatable concern in economic development (Anisimova, 2016; Arndt, Pauw \& Thurlow, 2015; Babalola, 2015; Kareem, Bakare, Ademoyewa, Ologunla \& Arije, 2015; Makhtar, 2017; Mogues, Morris, Freinkman, Adubi \& Ehui, 2008). Past studies have argued that the notion of public spending is connected to sustainable development. It is argued that a sustainability concept is in the scope of government expenditure (Aregbeyemi \& Kolawole, 2015; Baldos, Viens, Hertel \& Fuglie, 2018; Goyal \& Nash, 2016). Public spending is an economic instrument that government uses to maintain the economy and for development. Agriculture is the prime sector in terms of its contributions to Gross Domestic Product (GDP) and employment for most developing countries (Tenaye, 2020). Moreover, the majority of people existing in poverty globally obtained their income from agriculture and agricultural correlated activities in rural areas (Petkovová, Hartman \& Pavelka, 2020; Peón Pose, Martínez-Filgueira \& López-Iglesias, 2020; Siebrecht, 2020). Therefore, developing an effectual agricultural policy in developing countries must be highly significant and efficient government mechanisms must be put in place to propel agricultural growth (Alshahrani \& Alsadiq, 2014; Arndt et al., 2015; Fan, Hazell \& Thorat, 2000; Ojiako, Chianu, Johm \& Ojukwu, 2016; Rodrik, 2016).

Karamba \& Winters (2015) and Babatunde (2018) argued that cost-effective agricultural public expenditure enhances poverty reduction. Fan \& Zhang (2008) and Wu, Tang \& Lin (2010) indicated that cost-effective funding of drivers of agricultural growth like extension services, efficient credit delivery systems, research and development among others, bring about agricultural growth. However, evidence has shown that in developing countries, public expenditure on agriculture and on the drivers of agricultural growth is too low to bring about meaningful development (Diao, Fan, Kanyarukiga \& Yu, 2010; Manyong et al., 2005). Zhang \& Fan (2004) and Makhtar (2017) contended that identifying the drivers of growth and funding these drivers promptly is the key to meaningful agricultural growth.

Nigeria, since its inception, has set out policies that could transform the agricultural sector. Past studies argued that the country's huge agricultural resource base, which offers great potential for growth, has not really achieved that feat, due to poor funding, hence these policies could not influence agricultural growth (Chan, Ramly \& Abdkarim, 2017; Mogues et al., 2008). Manyong et al. (2005) revealed that in the 1960s, agriculture in Nigeria influenced about $64 \%$ of the total GDP, owing to the substantial investment the sector enjoyed both from public and private organizations. Kareem et al. (2015) indicated that in the 1970s agricultural contribution to GDP declined from 65\% in 1986 and to $48 \%$ in 1995 . There was a further decrease to $15 \%$ in 2008 . This study indicated that the root cause of this decline was the poor funding given to major drivers of agricultural growth which led to poor agricultural outputs (Takesshima \& Liverpool-Tasie, 2015). Evidence from other African countries like Zimbabwe revealed that government spending on agriculture was extraordinarily high (1990-2010) which yielded substantial agricultural outputs (Ansari, Gordon \& Akuamoah, 2007).

Coelli \& Prasada Rao (2005) examined the levels and trends in agricultural output and productivity in 93 developed and developing countries from 1980 and 2000. The results revealed that in Asia, the highest annual Total Factor Product (TFP) growth of $2.9 \%$ was achieved, followed by North America (US and Canada), Australia, Europe, and South America. However, developing countries (Sub Saharan Africa SSA, West Asia, Caribbean, and Oceania) experienced a decline of TFP because the regions (SSA) continued to rely on resource-led agricultural activities rather than productivity which the developed countries imbibed. Agricultural productivity returns on public spending in European countries are enormous (De Olde, Sautier \& Whitehead, 2020). The increase in enhanced agricultural productivity in developed countries derives from more intensive input use, advanced modern use of agricultural technology (which is highly funded), efficiency, managerial skills and organization of production 
(European Commission, 2016b; Kostlivý, Fuksová \& Dubec, 2017; Quiroga, Suárez, Fernández-Haddad \& Philippidis, 2017; Svilokos, Vojinić \& Tolić, 2019).

The above indicates that huge public spending brings about enhanced agricultural productivity. In most developing countries, like Nigeria, high public spending allocated to agriculture has not enhanced agricultural productivity. This is the gap the study has identified and the factors/drivers influencing these outcomes need to be studied. Consequently, the study examines factors/drivers of agricultural growth and public spending in Nigeria and whether the level of public spending prompts agricultural productivity. The main objective of the study is to examine quantity and quality of public spending and its effect on agricultural productivity. The study also explores the consequence of public spending on education, farm feeder roads and health care facilities and its effect on agricultural productivity. It is hoped that the outcome of this research would increase knowledge that can contribute to policy decision making in agricultural development. The paper hopes to contribute to literature about the efficiency of public spending and agricultural productivity.

Although there are large bodies of researchers that have examined the productivity effects of public expenditure, fewer studies have examined the drivers of agricultural growth and productivity effects, especially in Africa. The limited research on productivity effects of public agricultural expenditure in many developing countries was largely due to the lack of extended time series expenditure data and when they used were, it was for short periods of time (not more than 10 years). However, fewer studies -Benin \& Nin-Pratt (2015) for Africa; Benin, Mogues, Cudjoe \& Randriamamonjy (2012) for Ghana; Mogues, Fan \& Benin (2015) for Ethiopa; Fan, Nyange \& Rao (2012) for Tanzania; and Fan \& Zhang (2008) for Uganda- used longer period data and revealed that public expenditure influenced productivity and economic growth thus providing established evidence of the effect of public spending on agricultural productivity.

Understanding this effect can offer beneficial policy visions for the government to enhance the efficiency of its public spending on agriculture. In addition to physical inputs, agricultural productivity can also be enhanced by quality spending on health care services, educational services and farm feeder roads among others (Baldos et al., 2018). This paper eeks to achieve this objective by examining the effect of public funding on agricultural productivity in Nigeria across main agro-ecological regions (1981-2018), as well as assessing marginal effects of public spending on health care facilities, education and farm feeder roads and their returns to agricultural productivity.

The paper is ordered as follows: section one is the introduction; section two looks at the methodological approaches used in this study, while section three presents results and discussions. Section four concludes the paper.

\section{Methodology}

\subsection{Area of study}

The study area is major agro-ecological regions in Nigeria (Figure 1, Table 1). These are marginal/ short grass savannah, derived woodland/long grass savannah, rainforest and mangrove/swamp. Nigeria has a geographical area of 923,768 square kilometres with an estimated population of about 170 million (Central Bank of Nigeria's [CBN] 2016 estimates). It lies wholly within the tropics along the gulf of Guinea on the western coast of Africa. The country has highly diversified agro-ecological conditions, which makes it possible to produce a wide range of agricultural products. Less than $50 \%$ of the country's cultivable agricultural land is under cultivation. Moreover, smallholder and traditional farmers who use rudimentary production techniques, with resultant low yields, cultivate most of these lands. The country is divided into seven agro-ecological regions but four are distinctive and are used as the basis of analysis for this study (Figure 1). 


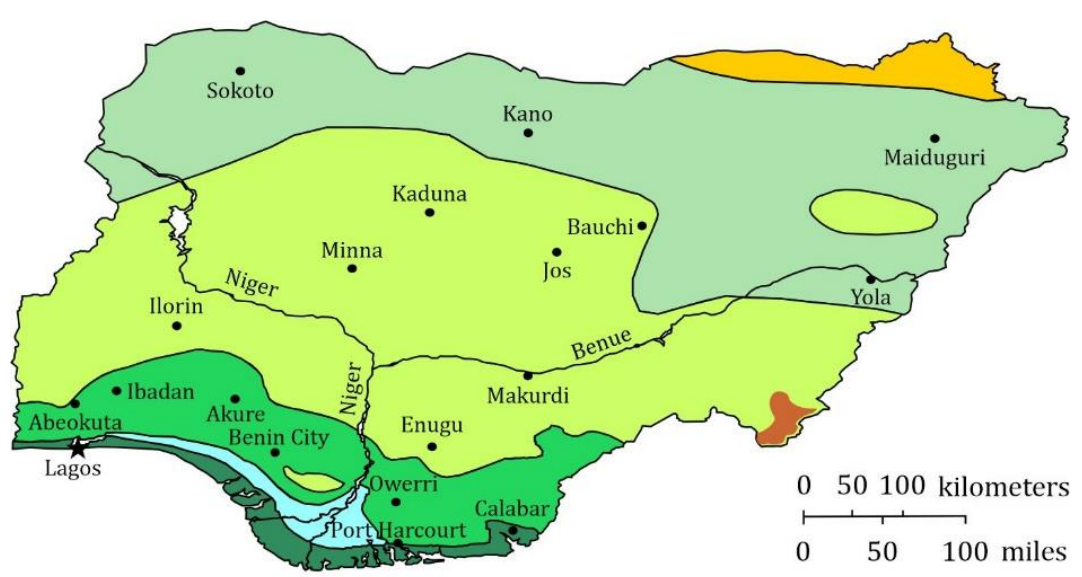
Marginal savanna
Short grass savanna
Woodland and tall grass savanna
Rainforest
Fresh water swamp
Mangrove
Montane

Figure 1. Map of Nigeria showing agro-ecological regions. Source: www.nigerianstat.gov.ng/nada/index.php/catalog

Table 1. Major agro-ecological regions in Nigeria

\begin{tabular}{|c|c|c|c|c|}
\hline $\mathrm{s} / \mathrm{n}$ & $\begin{array}{l}\text { Major } \\
\text { agro-ecological } \\
\text { zones }\end{array}$ & States & Major agricultural activities & Vegetation \\
\hline 1 & $\begin{array}{l}\text { Marginal/Short } \\
\text { grass savanna. }\end{array}$ & $\begin{array}{l}\text { Bauchi, Borno, Jigawa, } \\
\text { Kano, Katsina, Kebbi, } \\
\text { Sokoto, Yobe and } \\
\text { Zamfara. }\end{array}$ & $\begin{array}{l}\text { Cotton, groundnut, sorghum, millet, maize } \\
\text { and wheat. Locust bean trees (Parkia } \\
\text { filicoidea), tamarind tree (Tamarindus } \\
\text { indica) and mango (Mangifera indica). }\end{array}$ & $\begin{array}{l}\text { Low average annual } \\
\text { rainfall of } 657.3 \mathrm{~mm} \text { and } \\
\text { prolonged dry season } \\
\text { (6-9 months). }\end{array}$ \\
\hline 2 & $\begin{array}{l}\text { Derived } \\
\text { woodland/Long } \\
\text { grass savanna. }\end{array}$ & $\begin{array}{l}\text { Abuja, Adamawa, } \\
\text { Benue, Gombe, } \\
\text { Kaduna, Kogi, Kwara, } \\
\text { Nassarawa, Niger, } \\
\text { Plateau and Taraba. }\end{array}$ & $\begin{array}{l}\text { Grazing livestock such as cattle, goats, } \\
\text { horses, sheep, camels, and donkeys. Maize, } \\
\text { cassava, yam and rice. }\end{array}$ & $\begin{array}{l}\text { This zone experiences } \\
\text { lower rainfall, shorter } \\
\text { rainy season and long dry } \\
\text { period. }\end{array}$ \\
\hline 3 & Rainforest. & $\begin{array}{l}\text { Abia, Anambra, Ebonyi, } \\
\text { Edo, Ekiti, Enugu, } \\
\text { Ogun, Ondo, Osun, and } \\
\text { Oyo. }\end{array}$ & $\begin{array}{l}\text { Staple crops like, yam, cassava, cocoyam, } \\
\text { sweet potatoes, melon, groundnut, rice } \\
\text { maize and oil palm (Elaeis guineensis), } \\
\text { cocoa (Theobroma cacao), rubber (Hevea } \\
\text { brasiliensis) banana/plantain (Musa spp.), } \\
\text { cotton and kola nut (Cola nitida). Cowpeas } \\
\text { and beans as well as several fruits. Various } \\
\text { timber trees such as the African mahogany, } \\
\text { the scented sapele wood Entandrophragma } \\
\text { cylindricum) and iroko (Chlorophora } \\
\text { excelsa). }\end{array}$ & $\begin{array}{l}\text { Prolonged rainy season, } \\
\text { resulting in high annual } \\
\text { rainfall above } 2000 \mathrm{~mm} \text {. }\end{array}$ \\
\hline 4 & Mangrove/Swamp. & $\begin{array}{l}\text { Akwa Ibom, Bayelsa, } \\
\text { Cross Rivers, Delta, } \\
\text { Lagos and Rivers. }\end{array}$ & $\begin{array}{l}\text { Oil-palm, cocoa, cassava, maize, yam. } \\
\text { Various palm and fiber plants such as } \\
\text { Raphia spp., Raphia vinifera, the wine palm } \\
\text { and Raphia hookeri, the roof-mat palm. }\end{array}$ & $\begin{array}{l}\text { Prolonged rainy season } \\
\text { and lagoons overflow } \\
\text { banks in the wet season } \\
\text { (8-9 months). Thus longer } \\
\text { rains, has led to badly } \\
\text { leached soils and severe } \\
\text { erosion. }\end{array}$ \\
\hline
\end{tabular}

Sources: [1] https://soilsnigeria.net; [11] Oyenuga (1967); [iii] Materials from https://www.fao.org; [iv] Sowunmi \& Akintola (2010). 


\subsection{Method of data collection}

Due to the nature of this research, public expenditure on agricultural and related non-agricultural enterprises data were collected. Data were sourced from the Ministry for Agriculture and other significant ministries, departments, agencies, and offices responsible for finance, budget and planning. The study conceptualized agriculture and agricultural activities to include arable and covers crop, livestock, forestry and fisheries. Public expenditure was deduced as annual and complementary appropriations (budget) that support funding of direct and indirect agricultural activities. Public finance data were also sourced from the Ministry of Finance (Nigeria), public expenditure data from other key sectors, the Central Bank of Nigeria's (CBN) Statistical Bulletin (2018). Public expenditure data (1980-2018) on agriculture was obtained from the Budget and Economic Planning office (Federal Ministry of Finance Abuja), the National Bureau of Statistics' (NBS) annual abstract (various issues), and the Agricultural Development Project (ADP) Offices.

While public expenditure data on the non-agricultural sector at the national level for education, health care facilities and farm feeder roads were taken from the individual government ministries, departments and agencies, data on agricultural production, private farm investments and other farm-household physiognomies were sourced from the most recent National Living Standards Survey. Data on education and health care facilities and services access were acquired from the latest report of the Core Welfare Indicators Questionnaire (CWIQ). Data on farm feeder roads and associated information were sourced from the Federal Ministry of Transport and Aviation and State Ministries of Transport. These variables used in the analysis were presented in Table 2 . All monetary values were changed into year 2000 constant prices using the local consumer price index to exclude the influence of inflation and other temporal monetary and fiscal trends.

Table 2. Description and statistical summaries of major variables used

\begin{tabular}{|c|c|c|c|c|}
\hline $\begin{array}{l}\text { Variable } \\
\text { name }\end{array}$ & Variable description & Mean & $\begin{array}{c}\text { Standard } \\
\text { dev. }\end{array}$ & $\begin{array}{l}\text { Data } \\
\text { source }\end{array}$ \\
\hline TOAGR & $\begin{array}{l}\text { Total value of agricultural-output per capita of a household. It's also the } \\
\text { value of total agricultural investments made and inputs used by the } \\
\text { household in the survey scenario ( } \$ 6500 \text { naira per capita). }\end{array}$ & $5,872.27$ & 138.26 & $\begin{array}{l}\text { Min. of } \\
\text { Agric. }\end{array}$ \\
\hline PUEXP & $\begin{array}{l}\text { Labelled as a function of public expenditure in agriculture. It is also based } \\
\text { on: } \\
\text { (i) developmental expenditures and } \\
\text { (ii) recurrent expenditures. }\end{array}$ & $\begin{array}{c}43.05 \\
148.19\end{array}$ & $\begin{array}{c}6.16 \\
13.62\end{array}$ & $\begin{array}{l}\text { Annual } \\
\text { Budget } \\
\text { (various } \\
\text { issues) }\end{array}$ \\
\hline FACDEV & $\begin{array}{l}\text { Other factors influencing public-investment that motivate enterprise } \\
\text { growth in agriculture, like infrastructures (good farm access roads, storage } \\
\text { facilities), education, health care facilities. }\end{array}$ & 2.25 & 0.62 & $\begin{array}{l}\text { Annual } \\
\text { Budget } \\
\text { (various } \\
\text { issues) }\end{array}$ \\
\hline $\begin{array}{l}\text { Access } \\
\text { farm } \\
\text { roads }\end{array}$ & $\begin{array}{l}\text { This is to deduce the quality of farm-access roads to residences and } \\
\text { markets and its significance on income generation: rainforest/mangrove } \\
\text { (i) Good farm access roads: } 0.50 .250 .00 .0 \\
\text { (ii) Moderate farm access roads: } 0.50 .750 .750 .5 \\
\text { (iii) Poor farm access roads: } 0.00 .00 .250 .5\end{array}$ & $\begin{array}{l}1.5 \\
1.75 \\
2.25\end{array}$ & $\begin{array}{l}0.58 \\
0.50 \\
0.52\end{array}$ & CWIQ \\
\hline Education & $\begin{array}{l}\text { Proportion of household members that have completed level of formal } \\
\text { education and its significance on income generation: rainforest/mangrove } \\
\text { (i) No formal-education: } 0.50 .50 .00 .0 \\
\text { (ii) Completed primary school: } 0.50 .50 .250 .5 \\
\text { (iii) Completed secondary school: } 0.00 .00 .250 .5 \\
\text { (iv) Post-secondary attempt/completed: } 0.00 .00 .50 .0\end{array}$ & $\begin{array}{c}1.5 \\
2.5 \\
3.25 \\
2.5\end{array}$ & $\begin{array}{l}0.57 \\
0.58 \\
0.96 \\
0.58\end{array}$ & $\begin{array}{c}\text { Min. of } \\
\text { Education }\end{array}$ \\
\hline
\end{tabular}


Table 2 (continuation). Description and statistical summaries of major variables used

\begin{tabular}{|c|c|c|c|c|}
\hline $\begin{array}{l}\text { Variable } \\
\text { name }\end{array}$ & Variable description & Mean & $\begin{array}{l}\text { Standard } \\
\text { dev. }\end{array}$ & $\begin{array}{l}\text { Data } \\
\text { source }\end{array}$ \\
\hline $\begin{array}{l}\text { Access to } \\
\text { health }\end{array}$ & $\begin{array}{l}\text { Proportion of households living within vicinity of health facility: } \\
\text { (cf.: up to } 15 \text { minutes): rainforest/mangrove }\end{array}$ & & & CWIQ \\
\hline \multirow[t]{3}{*}{ care } & (i) 15-29 minutes: 0.000 .000 .250 .00 & 2.0 & 0.82 & \\
\hline & (ii) 30-44 minutes: 0.250 .500 .500 .25 & 2.5 & 0.58 & \\
\hline & (iii) 45 minutes or more: 0.750 .500 .250 .75 & 2.75 & 0.50 & \\
\hline \multirow[t]{23}{*}{ SOCIOXT } & Household characteristics: & & & CWIQ \\
\hline & (i) Household size: Number of household members (adult equivalents) & 5.93 & 1.65 & \\
\hline & (ii) Gender of head: Male $=1$ and Female $=0$ & 0.62 & 0.31 & \\
\hline & (iii) Age of head: Age of household head (years) & 51.23 & 5.28 & \\
\hline & (iv) Adult labour: Proportion of members aged 18 to 64 & 0.32 & 0.17 & \\
\hline & (v) Male labour: Proportion of members that are male & 0.47 & 0.21 & \\
\hline & (vi) Female labour: Proportion of members that are male & 0.52 & 0.43 & \\
\hline & $\begin{array}{l}\text { (vii) Employment: Proportion of members employed } \\
\text { (viii) Income diversification/strategy rainforest/mangrove }\end{array}$ & 0.35 & 0.08 & \\
\hline & Subsistence farming only: 0.00 .00 .500 .50 & 1.57 & 0.48 & \\
\hline & Semi commercial farming only: 0.00 .00 .00 .0 & 0.0 & 0.0 & \\
\hline & Subsistence farming + Market-oriented crops: 0.250 .250 .250 .25 & 2.0 & 1.41 & \\
\hline & Semi commercial farming + Market-oriented: 0.00 .00 .00 .0 & 0.0 & 0.0 & \\
\hline & Subsistence farming + Non-farm activity: 0.500 .250 .250 .25 & 3.25 & 0.96 & \\
\hline & $\begin{array}{l}\text { Semi commercial farming + Non-farm activity: } 0.250 .50 .00 .0 \\
\text { (ix) Farm assets characteristics rainforest/mangrove }\end{array}$ & 3.0 & 0.82 & \\
\hline & Population 2009 projections: 63500175458897172217525418640172 & 1502053 & $4,423.85$ & \\
\hline & Proportion of households living below poverty line (\%): 36.5333 .8732 .4338 .73 & 18 & 2 & \\
\hline & Total land area (1000 sq. km): 338,206 380,728 121,355 69,100 & 36.39 & 2.80 & \\
\hline & Farm size: Acres of farmland (\%): 37.1741 .9013 .517 .42 & 227347 & 38,431 & \\
\hline & Livestock assets: & & & \\
\hline & No of tropical livestock units: $11,936.415427 .92482 .52215 .30$ & & & \\
\hline & Value of crop production equipment & & & \\
\hline & (N20,000 per capita): 7203.15917 .31728 .17253 .28 & & & \\
\hline & $\%$ of population with agriculture as main activity: 71.2665 .0341 .0335 .17 & & & \\
\hline \multirow{9}{*}{$\begin{array}{l}A G R O \\
Z O N E\end{array}$} & Agro-ecological zones: & & & CWIQ \\
\hline & (i) Marginal/Short grass savanna; public expenditures on agriculture & 31.58 & 3.82 & \\
\hline & Marginal/Short grass savanna; agriculture contribution to GDP & 29.98 & 4.17 & \\
\hline & (ii) Derived woodland and long grass savanna; public expenditures on agric. & 47.17 & 5.24 & \\
\hline & Derived woodland and long grass savanna; agriculture contribution to GDP & 31.32 & 3.02 & \\
\hline & (iii) Rainforest; public expenditures on agriculture & 36.71 & 4.14 & \\
\hline & Rainforest; agriculture contribution to GDP & 25.27 & 5.02 & \\
\hline & (iv) Mangrove/Swamp: Public expenditures on agriculture & 17.64 & 6.16 & \\
\hline & Mangrove/Swamp: Agriculture contribution to GDP & 13.34 & 5.28 & \\
\hline
\end{tabular}

Source: Various federal and state government agencies.

\subsection{Empirical links between public expenditure and agricultural growth}

Public expenditure is a significant factor which aims at financing the incentives for development, creating a fertile ground for the promotion of private sector investments and enterprise growth. Hence, it could also influence enterprise growth. Several models have been used to examine this link. Fan et al. (2000) and Benin et al. (2009) modelled a simultaneous equation approach to establish the links between public expenditure and agricultural growth. These studies argued that the composition of 
public expenditure for major agricultural drivers should be paramount. Taking a lead from the works of Wu et al. (2010), the composition of government-expenditure is modelled:

$$
V_{i t}=k\left(P E X P G D P_{t}, G D P \%, D V_{t}, U_{t}\right)
$$

Where $V_{i t}$ is the share of $i t h$ sector (agricultural) in total government expenditure, $t$ for time, PEXPGDP is public expenditure as a percentage of GDP, $G D P \% t$ is per capita GDP, $D V_{t}$ is a dummy variable that is equal to 1 when macroeconomic regulations are implemented and equal to 0 otherwise. Macroeconomic regulations regulate monetary, fiscal, trade policies, exchange rate and inflation. $U_{t}$ are unexplained factors in the equation and can influence government expenditure efficiency. In order to avoid the possibility of an endogeneity problem with the independent variables, the GMM instrumental variable was adopted (Dhrymes, 1973). Moreover, $\mathrm{GMM}^{1}$ take care of any possible presence of unit roots or non-stationarity of variables that may cause spurious regression results. Hence equation (2) was structured to reflect this procedure and presented as:

$$
\text { TOAGR }=f\left(P U E X P, F A C D E V, \text { PRODET, DRIVERS, IDFACT }, \text { SOCIOXT }, \beta_{0} \beta_{1} \beta_{2}\right)
$$

where

TOAGR: Total value of agricultural output per capita of a household.

PUEXP: Function of public expenditure in agriculture (where $\operatorname{PUEXP}_{p}=$ PUEXP $_{c a}+$ PUEXP $_{r c}$ ).

PUEXP $P_{c a}$ : Public capital expenditure in agriculture.

PUEXP rc: Public recurrent expenditure in agriculture.

$F A C D E V$ : Other factors that motivate agricultural enterprise growth like infrastructures, farm feeder roads, education, access to quality health-care facilities.

PRODET: Production functions of the determinants of public spending to use.

DRIVERS: Drivers of agricultural growth that motivate enterprise-development like, research and development, credit delivery services, extension services.

IDFACT: Indirect factors influencing agricultural enterprise growth.

SOCIOXT: Socioeconomics characteristics and institutional factors that could influence production process.

$\beta_{0} \beta_{1} \beta_{2}$ : Are vectors of parameters to be estimated for the equation.

$$
\begin{gathered}
F A C D E V=f\left(P U E X P, \text { PRODET, DRIVERS, IDFACT }, \text { SOCIOXT }, \beta_{1} \beta_{2}\right) \\
\text { DRIVERS }=f\left(I N T E R P O L, \text { PRODTE, IDFACT, } \beta_{1} \beta_{2}\right)
\end{gathered}
$$

INTERPOL: Intervention policies of the government to stimulate and motivate enterprise growth in agriculture.

$\beta_{1} \beta_{2}$ : Are vectors of parameters to be estimated for the respective equations (3) and (4).

TOAGR: Captures the level of impact of public investments for enterprise growth in agriculture (equation 2).

Equation (3) examines enterprise growth within public expenditure and the indirect effects of public expenditure on enterprise growth. Equation (4) considers the location effects (agro-ecological zone of the country) of public expenditure and government intervention on the drivers of enterprise growth programs. Thus, by including public expenditure and intervention in other sectors in equation (4), the study tried to capture possible interactions between expenditure on the non-agricultural and agricultural sectors.

\footnotetext{
1 Dickey-Fuller approach have been used for tests of presence of unit roots or non-stationarity.
} 


\subsection{Marginal effect of public expenditure on agricultural growth}

Marginal effect of public investments on agricultural growth was estimated as:

$$
\in \text { DRIVERS }=\frac{d T O A G R}{d P U E X P}=\frac{\partial T O A G R}{\partial P U E X P}+\frac{\partial T O A G R}{\partial F A C D E V} X \frac{\partial F A C D E V}{\partial P U E X P}-\cdots-----
$$

$\in$ DRIVERS is the marginal effects of the drivers of agricultural growth that motivate enterprise development such as research and development, credit delivery services, extension services. Therefore, this equation measures the direct effect of public investment in agriculture.

$$
\text { Thus }=\frac{d T O A G R}{d P U E X P} \text { and } \frac{\partial T O A G R}{\partial P U E X P}+\frac{\partial T O A G R}{\partial F A C D E V} X \frac{\partial F A C D E V}{\partial P U E X P} \text {-captured the indirect effect }
$$

Equation (5) hypothesized the typical vector of production function estimates with respect to farm investments (i.e. factors of production and inputs). This equation captured the elasticity of agricultural productivity with respect to public investment in the other sectors ( $\in I D F A C T)$, which is a function of $\beta p$ $\beta k$ and $\beta a$, and can be obtained by:

$$
\in I D F A C T=\frac{d F A C D E V}{d I D F A C T}=\frac{\partial F A C D E V}{\partial I D F A C T}+\frac{\partial F A C D E V}{\partial P R O D E T} X \frac{\partial P R O D E T}{\partial I D F A C T}+\in \text { DRIVERS X } \frac{d T O A G R}{d P U E X P}
$$

\subsection{Marginal returns on public spending}

Marginal returns on public investments (i.e. the benefit-cost ratio or $B C R$ ) can be computed by multiplying equations (7) and (8) with the relevant ratio of agricultural output per capita to public investment (Benin et al., 2009; Fan et al., 2000):

$$
\begin{gathered}
B C R \text { DRIVERS }=\in \text { DRIVERS X } \frac{F A C D E V}{D R I V E R S} \\
B C R I D F A C T=\in I D F A C T X \frac{F A C D E V}{I D F A C T}
\end{gathered}
$$

Marginal returns provide information for comparing the relative benefits of an additional unit of public spending.

\subsection{Estimation techniques and concerns}

The study adopted estimation techniques of a Three-Stage Least Squares (3SLS) method to appraise equations (1), (2), (3), and (4) simultaneously, following a previous study (Amemiya, 1977). Past studies argued that the 3SLS method is best fit to estimate all coefficients in the equations simultaneously, while, equations that are under-identified are disregarded in the 3SLS estimation (Gallant \& Dale, 1979; Jorgenson \& Laffont, 1975). The 3SLS estimates were used to estimate the linear equations (eqns. 1-4) with cross-equation constraints (public expenditure) imposed, but with a diagonal covariance matrix of the disturbances across equations (Dhrymes, 1973).This process helps to obtain the parameter estimates that form a consistent estimate of the covariance matrix of the disturbances, which was used as a weighting matrix, this led to a model re-estimation to obtain new values of the parameters used in the subsequent equations.

Past studies argued that when these techniques and estimations are considered, some issues and concerns need to be clarified (Benin et al., 2009; Fan et al., 2000). Firstly, the estimation techniques 
require an equal number of observations for each of the independent variables and to address this concern, each low independent variable data will be aggregated upwards to be the same as others (Gallant \& Dale, 1979). In addition, in estimating the variance and standard errors, the study emulates the work of Hsieh \& Lai (1994) who adopted the delta method $(\epsilon)$ for the estimation technique. Hence, the typical form of the probable elasticities of the method:

$$
\in=f\left(\widehat{\beta_{0}} \widehat{\beta_{1}} \widehat{\beta_{2}}\right)
$$

Also, the variance of the probable elasticities, adopting the delta method and the variance-covariance matrix of the coefficients $\left(\sum \epsilon^{\wedge}\right)$, can be achieved using the general form:

$$
\operatorname{Var}(\epsilon)=\left[\left(\frac{\partial f}{\partial \beta 0}\right)\left(\frac{\partial f}{\partial \beta 1}\right)\left(\frac{\partial f}{\partial \beta 2}\right) \times \sum\left[\left(\frac{\partial f}{\partial \beta 0}\right)\left(\frac{\partial f}{\partial \beta 1}\right)\left(\frac{\partial f}{\partial \beta 2}\right)\right] T\right.
$$

Moreover, the identification issue in the equation that might occur during estimation especially in the equation (1) was addressed by exploiting exclusion restrictions i.e. excluding some of the explanatory variables (or instruments) used in estimating the equation (2). Another concern the study dealt with was the issue of multicollinearity due to a large set of explanatory variables data. Hence, the Variance Inflation Factor (VIF) was adopted to take care of this (Greene, 1993). The results of this study, however (to the knowledge of the researcher), do not reflect any biased estimates.

\section{Results and discussion}

\subsection{Public expenditure on agriculture in agro-ecological regions and contribution to Gross Domestic Product (1981-2018)}

Table 3 reviewed public spending on agriculture in main agro-ecological regions and its contribution to GDP from 1981-2018. The results indicated that from 1981-2018, the share of statutory budget (public spending) allocation to agricultural development was $4.88 \%$ across zones, but the marginal/short grass savanna agro-ecological region received the highest $(7.32 \%)$, while the mangrove/swamp agro-ecological zone received $2.39 \%$. The agricultural contribution to GDP (\%) from 1981-2018 averaged $35.14 \%$ with the marginal/short grass savanna agro-ecological area reaching $29.13 \%$ while the mangrove/swamp agro-ecological area stood at $4.32 \%$. Total funding (shares) to the agricultural sector also indicated $32.52 \%, 47.16 \%, 37.80 \%$, and $17.82 \%$ for marginal/short grass savanna, derived/woodland long grass savanna, rainforest and mangrove/swamp agro-ecological areas respectively.

The results revealed that public spending on agricultural sectors across the agro-ecological zones had been very poor. Often, intervention of both local and foreign direct investments has been used to augment and finance agricultural projects in Nigeria. Intervention of both local and foreign direct investments on agriculture during the years under focus showed $63.47 \%, 76.51 \%, 80.34 \%$ and $74.69 \%$ in marginal/short grass savanna, derived/woodland long grass savanna, rainforest and mangrove/swamp agro-ecological regions respectively (Table 3). This finding was corroborated by the studies of Mongues et al. (2008) and Manyong et al. (2005) who acknowledged the role these intervention agencies (local and foreign direct investments) played in agricultural development in Nigeria.

Concerns arise about whether public funding in agriculture enhanced agricultural productivity in the identified agro-ecological zones, particularly the marginal/short grass savanna. This may be considered in future research. 
Table 3. Agricultural budget and expenditure appropriation for agro-ecological zones and contribution to GDP (1981-2018)

\begin{tabular}{|c|c|c|c|c|c|}
\hline Major agro-ecological zones & $\begin{array}{l}\text { Share of States } \\
\text { Statutory Budget } \\
\text { allocation to } \\
\text { agricultural } \\
\text { development (\%) }\end{array}$ & $\begin{array}{l}\text { Share of Federal } \\
\text { Government } \\
\text { intervention to } \\
\text { agricultural } \\
\text { develop. (\%) }\end{array}$ & $\begin{array}{c}\text { Share of Local } \\
\text { and International } \\
\text { Aids/Intervention } \\
\text { to agricultural } \\
\text { development (\%) }\end{array}$ & $\begin{array}{l}\text { Total funding } \\
\text { (shares) to } \\
\text { agricultural } \\
\text { sector }(\%)\end{array}$ & $\begin{array}{l}\text { Agriculture } \\
\text { contribution } \\
\text { to GDP (\%) }\end{array}$ \\
\hline \multicolumn{6}{|l|}{ 1981-1985 35.10* } \\
\hline $\begin{array}{l}\text { Marginal/Short grass savanna } \\
\text { Derived/Woodland and long grass savanna } \\
\text { Rainforest } \\
\text { Mangrove/Swamp }\end{array}$ & $\begin{array}{l}07.62 \\
06.72 \\
05.27 \\
02.62\end{array}$ & $\begin{array}{l}05.01 \\
06.03 \\
04.92 \\
02.72\end{array}$ & $\begin{array}{l}26.02 \\
41.05 \\
24.02 \\
08.91\end{array}$ & $\begin{array}{l}38.65 \\
53.80 \\
34.21 \\
14.25\end{array}$ & $\begin{array}{l}40.02 \\
24.94 \\
23.01 \\
12.03\end{array}$ \\
\hline \multicolumn{6}{|l|}{$1986-199036.58^{*}$} \\
\hline $\begin{array}{l}\text { Marginal/Short grass savanna } \\
\text { Derived/Woodland and long grass savanna } \\
\text { Rainforest } \\
\text { Mangrove/Swamp }\end{array}$ & $\begin{array}{l}07.02 \\
05.62 \\
03.18 \\
02.16\end{array}$ & $\begin{array}{l}06.12 \\
05.14 \\
03.83 \\
02.92\end{array}$ & $\begin{array}{l}29.83 \\
42.88 \\
22.81 \\
07.27\end{array}$ & $\begin{array}{l}42.97 \\
53.64 \\
29.82 \\
12.35\end{array}$ & $\begin{array}{l}23.71 \\
39.52 \\
25.04 \\
11.73\end{array}$ \\
\hline \multicolumn{6}{|l|}{ 1991-1995 32.66* } \\
\hline $\begin{array}{l}\text { Marginal/Short grass savanna } \\
\text { Derived/Woodland and long grass savanna } \\
\text { Rainforest } \\
\text { Mangrove/Swamp }\end{array}$ & $\begin{array}{l}05.17 \\
04.04 \\
03.92 \\
02.02\end{array}$ & $\begin{array}{l}05.04 \\
05.20 \\
03.18 \\
02.03\end{array}$ & $\begin{array}{l}13.07 \\
29.83 \\
45.05 \\
12.05\end{array}$ & $\begin{array}{l}23.28 \\
39.07 \\
52.15 \\
16.10\end{array}$ & $\begin{array}{l}24.84 \\
27.47 \\
29.31 \\
18.38\end{array}$ \\
\hline \multicolumn{6}{|l|}{$1996-200033.08^{*}$} \\
\hline $\begin{array}{l}\text { Marginal/Short grass savanna } \\
\text { Derived/Woodland and long grass savanna } \\
\text { Rainforest } \\
\text { Mangrove/Swamp }\end{array}$ & $\begin{array}{l}06.05 \\
05.47 \\
03.45 \\
02.37\end{array}$ & $\begin{array}{l}05.21 \\
05.82 \\
03.29 \\
02.05\end{array}$ & $\begin{array}{l}12.45 \\
31.54 \\
41.29 \\
14.72\end{array}$ & $\begin{array}{l}23.71 \\
42.83 \\
48.03 \\
19.14\end{array}$ & $\begin{array}{l}26.01 \\
31.36 \\
27.38 \\
15.25\end{array}$ \\
\hline \multicolumn{6}{|l|}{$2001-200538.42 *$} \\
\hline $\begin{array}{l}\text { Marginal/Short grass savanna } \\
\text { Derived/Woodland and long grass savanna } \\
\text { Rainforest } \\
\text { Mangrove/Swamp }\end{array}$ & $\begin{array}{l}07.67 \\
06.25 \\
04.46 \\
02.84\end{array}$ & $\begin{array}{l}04.86 \\
05.14 \\
03.06 \\
02.64\end{array}$ & $\begin{array}{l}11.85 \\
28.18 \\
35.07 \\
24.90\end{array}$ & $\begin{array}{l}24.38 \\
39.57 \\
42.59 \\
30.38\end{array}$ & $\begin{array}{l}31.05 \\
26.91 \\
27.82 \\
14.22\end{array}$ \\
\hline \multicolumn{6}{|l|}{$2006-201031.72^{*}$} \\
\hline $\begin{array}{l}\text { Marginal/Short grass savanna } \\
\text { Derived/Woodland and long grass savanna } \\
\text { Rainforest } \\
\text { Mangrove/Swamp }\end{array}$ & $\begin{array}{l}8.20 \\
7.60 \\
4.70 \\
2.31\end{array}$ & $\begin{array}{l}04.52 \\
04.38 \\
02.91 \\
01.63\end{array}$ & $\begin{array}{l}27.81 \\
42.06 \\
17.85 \\
12.28\end{array}$ & $\begin{array}{l}40.53 \\
54.04 \\
25.46 \\
16.22\end{array}$ & $\begin{array}{l}32.61 \\
34.05 \\
22.28 \\
11.06\end{array}$ \\
\hline \multicolumn{6}{|l|}{ 2011-2015 21.35* } \\
\hline $\begin{array}{l}\text { Marginal/Short grass savanna } \\
\text { Derived/Woodland and long grass savanna } \\
\text { Rainforest } \\
\text { Mangrove/Swamp }\end{array}$ & $\begin{array}{l}6.82 \\
6.31 \\
3.82 \\
1.70\end{array}$ & $\begin{array}{l}03.85 \\
03.82 \\
02.03 \\
01.57\end{array}$ & $\begin{array}{l}23.43 \\
37.06 \\
26.47 \\
13.04\end{array}$ & $\begin{array}{l}34.10 \\
47.19 \\
32.32 \\
16.31\end{array}$ & $\begin{array}{l}30.80 \\
33.05 \\
23.63 \\
12.52\end{array}$ \\
\hline \multicolumn{6}{|l|}{ 2016- $201824.85^{*}$} \\
\hline $\begin{array}{l}\text { Marginal/Short grass savanna } \\
\text { Derived/Woodland and long grass savanna } \\
\text { Rainforest } \\
\text { Mangrove/Swamp }\end{array}$ & $\begin{array}{l}7.01 \\
6.48 \\
5.16 \\
3.01\end{array}$ & $\begin{array}{l}04.39 \\
04.17 \\
04.02 \\
02.06\end{array}$ & $\begin{array}{l}24.05 \\
37.28 \\
28.05 \\
13.41\end{array}$ & $\begin{array}{l}36.28 \\
47.44 \\
36.11 \\
18.05\end{array}$ & $\begin{array}{l}33.82 \\
36.17 \\
28.02 \\
14.17\end{array}$ \\
\hline
\end{tabular}

Notes: *aggregate value for the scenarios considered. Sources: Federal Ministry of Agriculture and Rural Development (FMARD), FAOSTAT data 2005 and 2015, World Bank, NBS: Annual abstract of statistics (various issues), Central Bank of Nigeria - Statistical Bulletin (various issues), Federal Ministry of Finance (Budget office), Authors' computation based on data from SPARC (2014): Based on data from Federal Ministry of Agriculture and Rural Development, and State Ministries (1981-2014). 


\subsection{Regression estimates of the determinants of agricultural production in the agro-ecological zones of Nigeria}

Three-stage least squares (3SLS) regression results were presented in Tables 4 and 5 . Analyses were done in phases, firstly, by means of the joint total sample and then separately for the four agro-ecological zones. The analysis was based on the data provided to update equations (2) and (3).

Table 4. Three-stage least squares regression estimates of the determinants of agricultural production in Nigeria (Equation 2: Ln TOAGRk): Using aggregate public agricultural expenditures

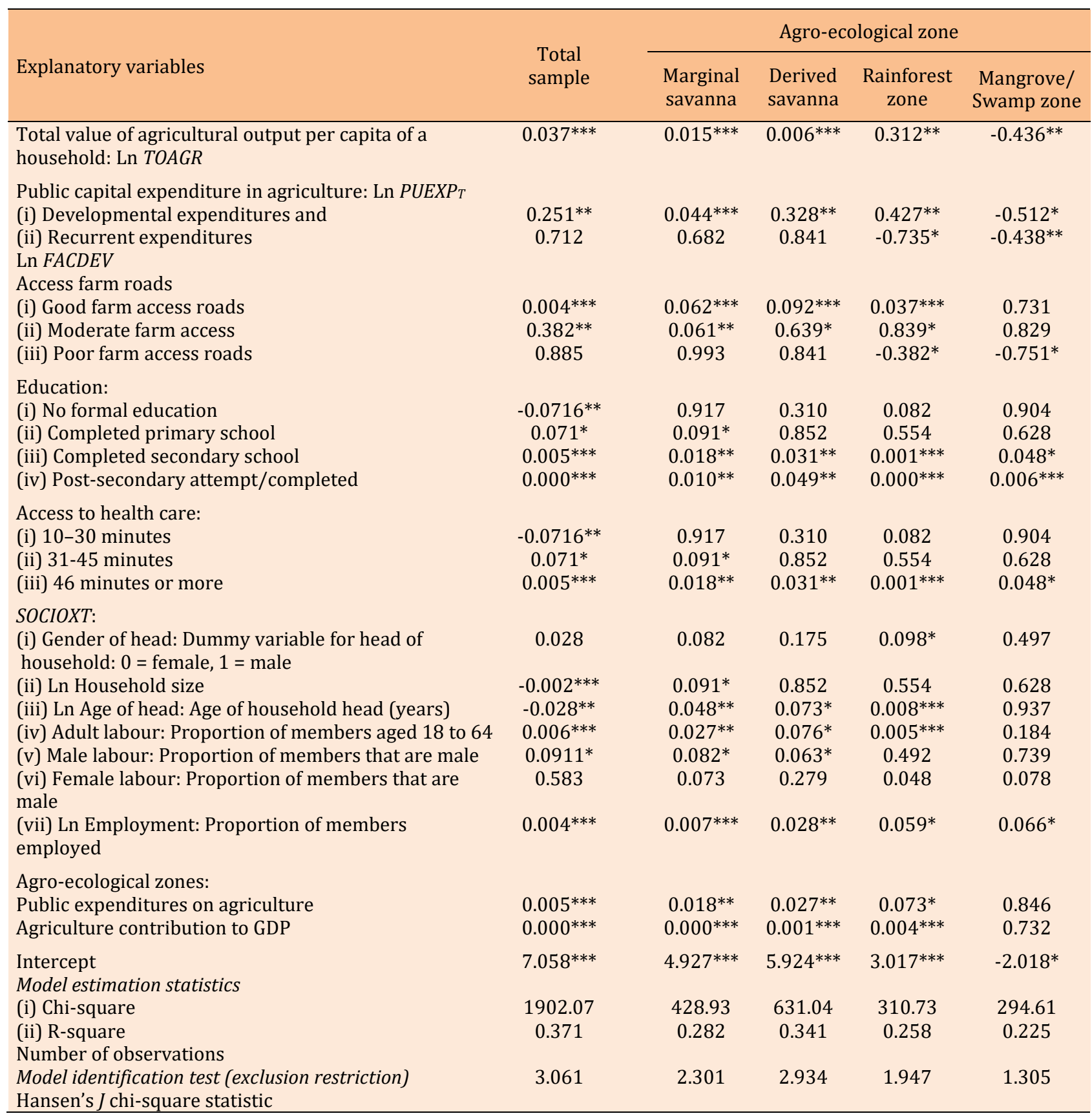

Notes: See Table 2 for a detailed description of the variables. All continuous variables are transformed by natural logarithm, which is indicated by $\mathrm{Ln}^{*}, * *$ and ${ }^{* *}$ means that the coefficient is statistically significant at the 10 percent, 5 percent or 1 percent level, respectively. Source: own elaboration. 
Table 5. 3SLS regression estimates of the determinants of agricultural production in Nigeria (Equation 3: Ln $F A C D E V_{p}$ ): Using aggregate public agricultural expenditures

\begin{tabular}{|c|c|c|c|c|c|}
\hline \multirow{2}{*}{ Explanatory variables } & \multirow{2}{*}{$\begin{array}{c}\text { Total } \\
\text { sample }\end{array}$} & \multicolumn{4}{|c|}{ Agro-ecological zone } \\
\hline & & $\begin{array}{l}\text { Marginal } \\
\text { savanna }\end{array}$ & $\begin{array}{l}\text { Derived } \\
\text { savanna }\end{array}$ & $\begin{array}{l}\text { Rainforest } \\
\text { zone }\end{array}$ & $\begin{array}{c}\text { Mangrove/ } \\
\text { Swamp zone }\end{array}$ \\
\hline Ln PUEXP & $0.005^{* * *}$ & $0.0400^{* *}$ & $0.0410^{* *}$ & $0.062^{*}$ & -0.942 \\
\hline $\begin{array}{l}\text { (i) Developmental expenditures and } \\
\text { (ii) Recurrent expenditures }\end{array}$ & $-0.0301^{*}$ & $0.714^{*}$ & 0.649 & $-0.021^{* *}$ & $-0.007^{* * *}$ \\
\hline \multicolumn{6}{|l|}{ Ln Access farm roads } \\
\hline (i) Good farm access roads & $0.023^{* *}$ & $0.075^{*}$ & $0.029 * *$ & 0.713 & 0.615 \\
\hline (ii) Moderate farm access & $0.016^{* *}$ & $0.032^{* *}$ & $0.062^{*}$ & 0.912 & 0.814 \\
\hline (iii) Poor farm access roads & $-0.062^{*}$ & 0.617 & 0.153 & $-0.032^{* *}$ & $-0.077^{*}$ \\
\hline \multicolumn{6}{|l|}{ Education: } \\
\hline (i) No formal education & $-0.005^{* * *}$ & $0.013^{* *}$ & 0.418 & 0.995 & $-0.043^{* *}$ \\
\hline (ii) Completed primary school & $0.034^{* *}$ & $0.083^{*}$ & 0.401 & 0.703 & $0.001^{* * *}$ \\
\hline (iii) Completed secondary school & $0.000^{* * *}$ & $0.001^{* * *}$ & $0.004^{* * *}$ & $0.000^{* * *}$ & $0.010^{* *}$ \\
\hline (iv) Post-secondary attempt/completed & $0.000^{* * *}$ & $0.000^{* * *}$ & $0.000^{* * *}$ & $0.000^{* * *}$ & $0.000^{* * *}$ \\
\hline \multicolumn{6}{|l|}{ Access to health care: } \\
\hline (i) 10-30 minutes & $0.003^{* * *}$ & $0.044^{* *}$ & $0.005^{* * *}$ & $0.013^{* *}$ & $0.037^{* *}$ \\
\hline (ii) 31-45 minutes & $0.031^{* *}$ & $0.084^{*}$ & 0.852 & 0.930 & 0.111 \\
\hline (iii) 46 minutes or more & $-0.003^{* * *}$ & $-0.038^{* *}$ & $-0.048^{* *}$ & $-0.008^{* * *}$ & $-0.017^{* *}$ \\
\hline \multicolumn{6}{|l|}{ SOCIOXT: } \\
\hline (i) Gender of head & $0.014^{* *}$ & $0.015^{* *}$ & $0.008^{* * *}$ & $0.042^{* *}$ & $0.067^{* *}$ \\
\hline (ii) Ln Household size & $0.000^{* * *}$ & $0.000^{* * *}$ & $0.005^{* * *}$ & $0.006^{* * *}$ & 0.910 \\
\hline (iii) Ln Age of head: Age of household head (years) & $0.084^{*}$ & $0.017^{* *}$ & $0.027^{* *}$ & $0.003^{* * *}$ & $-0.025^{* *}$ \\
\hline (iv) Adult labour: Proportion of members aged 18-64 & $0.009 * * *$ & $0.047^{* *}$ & $0.000^{* * *}$ & $0.018^{* *}$ & 0.837 \\
\hline $\begin{array}{l}\text { (v) Employment: Proportion of members employed } \\
\text { Income diversification/strategy: }\end{array}$ & 0.927 & 0.187 & 0.672 & 0.816 & 0.328 \\
\hline (i) Subsistence farming only & $0.048^{* *}$ & 0.946 & $0.074^{* *}$ & $0.007^{* * *}$ & 0.729 \\
\hline (ii) Subsistence farming + Market-oriented crops & $0.008^{* * *}$ & $0.010^{* *}$ & $0.000^{* * *}$ & $0.006^{* * *}$ & $0.071^{*}$ \\
\hline (iii) Subsistence farming + Non-farm activity & $0.008^{* * *}$ & $0.004^{* * *}$ & $0.000^{* * *}$ & $0.006^{* * *}$ & $0.067^{*}$ \\
\hline (iv) Semi commercial farming + Non-farm activity & $0.001^{* * *}$ & $0.002^{* * *}$ & $0.004^{* * *}$ & $0.027^{* *}$ & 0.927 \\
\hline $\begin{array}{l}\text { Intercept } \\
\text { Model estimation statistics }\end{array}$ & $0.082^{*}$ & 0.962 & $0.091^{*}$ & $0.052^{*}$ & 0.862 \\
\hline \multicolumn{6}{|l|}{ Model estimation statistics } \\
\hline Chi-square & 6281.06 & 2800.14 & 4320.91 & 3006.16 & 1104.52 \\
\hline$R$-square & 0.574 & 0.497 & 0.503 & 0.417 & 0.389 \\
\hline Number of observations & & & & & \\
\hline
\end{tabular}

Notes: See Table 2 for a detailed description of the variables. All continuous variables are transformed by natural logarithm, which is indicated by Ln. *, ** and ${ }^{* * *}$ means that the coefficient is statistically significant at the 10 percent, 5 percent or 1 percent level, respectively. Source: own elaboration.

Tables 4 and 5 clearly indicated the significant role public spending played in agricultural output and factors influencing agricultural productivity. Public spending on the agricultural sector (1981-2018) had a significant and positive impact on agricultural output. The Model Statistics R-square of 52.3\% indicated a moderately goodfit. Moreover, most of the variables considered had their explanatory variables coefficients statistically significant at the $10 \%, 5 \%$ or $1 \%$ level, respectively. The regression results reveal that public spending on the agricultural sector in recent years has had a substantial positive influence on agricultural productivity, either directly or through better private farm investments. For all the zones together, the marginal effect is assessed at 0.037 (Table 4). This means that a one percent increase in agricultural public expenditure is related to a 0.04 percent increase in the value of agricultural production per capita. 


\subsection{Public agricultural spending and marginal agricultural productivity effects}

Regression estimates of the drivers of agricultural public expenditure in Nigeria were presented in Table 6. Model fit indicators revealed $R^{2}$ of 0.54 , which is $54 \%$ of the independent variables considered and thus explained the model. The access to farm road variable was 0.045 , the access to education variable was 0.071 and access to health (within 15-30 minutes' walk to health facility) was 0.013 , all significant at $1 \%$ level suggesting that a $1 \%$ increase in the funding of education access, farm feeder roads and health facilities will enhance agricultural productivity per capita by 0.043 . Regression estimates of the drivers of agricultural public expenditure in Nigeria (Equation 4: Ln PUEXP $P_{T}$ ) were presented in Table 6. Moderate access to farm roads was significant and positive (for capital expenditure), but insignificant for recurrent expenditure. This result suggests that poor farm access roads contributed negatively to agricultural productivity. In addition, secondary school education completing the above variables was a significant factor enhancing human development which translates to productivity. The access to health care variable (where the majority could walk to health facilities centres within 45 minutes) revealed a positive significance.

Table 6. Ordinary least squares regression estimates of the drivers of agricultural public expenditure in Nigeria (Equation 4: Ln $P U E X P_{T}$ ) using aggregate public agricultural expenditure

\begin{tabular}{|c|c|c|c|}
\hline Explanatory variables & PUEXP $_{\text {Total }}$ & PUEXP $P_{\text {capital exp }}$ & PUEXP $_{\text {recurrent exp }}$ \\
\hline \multicolumn{4}{|l|}{ DRIVERS } \\
\hline $\begin{array}{l}\text { Ln Access farm roads: } \\
\text { (i) Good farm access roads } \\
\text { (ii) Moderate farm access } \\
\text { (iii) Poor farm access roads }\end{array}$ & $\begin{array}{c}0.045^{* * *} \\
0.067^{*} \\
-0.072^{*}\end{array}$ & $\begin{array}{c}0.032^{* *} \\
0.082^{*} \\
-0.062^{*}\end{array}$ & $\begin{array}{c}0.326^{*} \\
0.824 \\
-0.007^{* * *}\end{array}$ \\
\hline $\begin{array}{l}\text { Education: } \\
\text { (i) No formal education } \\
\text { (ii) Completed primary school } \\
\text { (iii) Completed secondary school } \\
\text { (iv) Post-secondary attempt/completed }\end{array}$ & $\begin{array}{c}0.842 \\
-0.041^{* *} \\
0.071^{* * *} \\
0.000^{* * *}\end{array}$ & $\begin{array}{c}0.518 \\
0.619 \\
0.043^{* *} \\
0.000^{* * *}\end{array}$ & $\begin{array}{c}0.739 \\
0.618 \\
0.042^{* *} \\
0.007^{* * *}\end{array}$ \\
\hline $\begin{array}{l}\text { Access to health care: } \\
\text { (i) } 10-30 \text { minutes } \\
\text { (ii) } 31-45 \text { minutes } \\
\text { (iii) } 46 \text { minutes or more }\end{array}$ & $\begin{array}{c}0.013^{* * *} \\
0.036^{* *} \\
-0.033^{* *}\end{array}$ & $\begin{array}{l}0.007^{* * *} \\
0.052^{*} \\
-0.025^{* *}\end{array}$ & $\begin{array}{c}0.025^{* *} \\
0.839 \\
-0.046^{* *}\end{array}$ \\
\hline $\begin{array}{l}\text { SOCIOXT: } \\
\text { Ln Population } \\
\text { Ln Proportion of households living below poverty line } \\
\text { Ln Total land area } \\
\text { Ln Farm size: Acres of farmland } \\
\text { Ln Livestock assets: } \\
\text { Ln Value of crop production equipment } \\
\text { Ln \% of population with agriculture as main activity }\end{array}$ & $\begin{array}{c}0.583 \\
0.937 \\
0.617 \\
0.056^{*} \\
0.038^{* *} \\
0.052^{*} \\
-0.071^{*}\end{array}$ & $\begin{array}{c}0.618 \\
0.738 \\
0.613 \\
0.043^{* *} \\
0.017^{* *} \\
0.048^{* *} \\
0.005^{* * *}\end{array}$ & $\begin{array}{c}0.528 \\
-0.045^{* *} \\
0.816 \\
-0.068^{*} \\
0.062^{*} \\
-0.082^{*} \\
-0.083^{*}\end{array}$ \\
\hline $\begin{array}{l}\text { Agro-ecological zones: } \\
\text { (i) Marginal/Short grass savanna } \\
\text { (ii) Derived/Woodland and long grass savanna } \\
\text { (iii) Rainforest } \\
\text { (iv) Mangrove/Swamp }\end{array}$ & $\begin{array}{c}0.006^{* * *} \\
0.002^{* * *} \\
0.032^{* *} \\
0.069^{*}\end{array}$ & $\begin{array}{c}0.000^{*} \\
0.000^{*} \\
0.015^{* *} \\
0.052^{*}\end{array}$ & $\begin{array}{c}0.835 \\
0.628 \\
-0.081^{*} \\
-0.095^{*}\end{array}$ \\
\hline $\begin{array}{l}\text { Intercept } \\
R \text {-square } \\
\text { Number of observations } \\
F \text {-test statistic } \\
\end{array}$ & $\begin{array}{c}6.045^{* * *} \\
0.525 \\
8500 \\
9.717^{* * *} \\
\end{array}$ & $\begin{array}{c}5.015^{* * *} \\
0.473 \\
8500 \\
8.205^{* * *}\end{array}$ & $\begin{array}{c}4.927^{* * *} \\
0.620 \\
8500 \\
7.417^{* * *}\end{array}$ \\
\hline
\end{tabular}

Notes: See Table 1 for a detailed description of the variables. All continuous variables are transformed by natural logarithm, which is indicated by Ln. *,** and ${ }^{* * *}$ means that the coefficient is statistically significant at the 10 percent, 5 percent or 1 percent level, respectively. Source: own elaboration. 


\subsection{Marginal effects (elasticities) of public expenditure on agricultural productivity in Nigeria}

Table 7 indicated the effect of public spending on the value of agricultural production per capita. This result fluctuates substantially across the four agro-ecological zones. The marginal effect of the analysis was positive and statistically significant across all four. The marginal effects of PUEXP $P_{C E}$ were insignificant only for the mangrove/swamp zone but significant in the other agro-ecological areas, with elasticities of $0.782,0.041,0.042$ and 0.35 in mangrove savanna, derived savanna, rainforest and mangrove/swamp zones respectively (Table 7). Access to education, access to farm roads and access to health care variables all played a significant and positive role in enhancing agricultural productivity. However, there were a few exceptions, particularly, the variable PUEXP $P_{R E}$ on access to farm roads. The resulting effect of the insignificance of PUEXP $R E$ in the mangrove/swamp zone was due to the neutralizing negative effects related to recurring spending. In addition, recurrent expenditure was negative and significant in the rainforest area due to the response of the variable as an exclusive driving force of agricultural productivity (Table 7).

Table 7. Marginal effects (elasticities) of public expenditures in Nigeria

\begin{tabular}{|c|c|c|c|c|c|}
\hline \multirow{2}{*}{ Explanatory variables } & \multirow{2}{*}{$\begin{array}{c}\text { Total } \\
\text { sample }\end{array}$} & \multicolumn{4}{|c|}{ Agro-ecological zone } \\
\hline & & $\begin{array}{c}\text { Marginal } \\
\text { savanna }\end{array}$ & $\begin{array}{l}\text { Derived } \\
\text { savanna }\end{array}$ & $\begin{array}{c}\text { Rainforest } \\
\text { zone }\end{array}$ & $\begin{array}{l}\text { Mangrove/ } \\
\text { Swamp zone }\end{array}$ \\
\hline \multicolumn{6}{|l|}{ Agriculture } \\
\hline$P_{U E X P_{T N}}$ & $0.026 * *$ & $0.014^{* *}$ & $0.017^{* *}$ & $0.037^{* *}$ & $0.071^{*}$ \\
\hline$P U E X P_{C E}$ & $0.018^{* *}$ & $0.035^{* *}$ & $0.042^{* *}$ & $0.041^{* *}$ & 0.782 \\
\hline$P U E X P_{R E}$ & $-0.047^{* *}$ & $-0.028^{* *}$ & $0.037^{* *}$ & $-0.031^{* *}$ & 0.419 \\
\hline \multicolumn{6}{|l|}{ Education } \\
\hline$P U E X P_{T N}$ & $0.064 *$ & $0.092^{*}$ & $0.084^{*}$ & $0.025^{* *}$ & 0.626 \\
\hline$P U E X P_{C E}$ & $0.077^{*}$ & $0.062^{*}$ & $0.033^{* *}$ & $0.080 *$ & 0.506 \\
\hline$P U E X P_{R E}$ & $0.006^{* * *}$ & $0.011^{* *}$ & $0.025^{* *}$ & $0.062 *$ & 0.371 \\
\hline \multicolumn{6}{|l|}{ Access farm roads } \\
\hline$P U E X P_{T N}$ & $0.004^{* * *}$ & $0.002^{* * *}$ & $0.009 * * *$ & $0.064^{* *}$ & $0.001^{* * *}$ \\
\hline$P U E X P_{C E}$ & $0.007^{* * *}$ & $0.005^{* * *}$ & $0.002^{* *}$ & $0.048^{* *}$ & 0.817 \\
\hline$P U E X P_{R E}$ & $-0.024^{* *}$ & $-0.017^{* *}$ & $0.047^{* *}$ & $-0.062^{* *}$ & 0.502 \\
\hline \multicolumn{6}{|l|}{ Access to health care } \\
\hline$P_{U E X P_{T N}}$ & $0.008^{* * *}$ & $0.001^{* * *}$ & $0.000^{* * *}$ & $0.000^{* * *}$ & $0.004^{* * *}$ \\
\hline$P U E X P_{C E}$ & $0.007^{* *}$ & $0.002^{* * *}$ & $0.002^{* * *}$ & $0.000^{* * *}$ & $0.021^{* *}$ \\
\hline$P U E X P_{R E}$ & 0.219 & 0.772 & 0.618 & 0.529 & 0.916 \\
\hline
\end{tabular}

Notes: Authors' calculations based on Tables 9 and 10 and equations and (4), (4') and (9). Estimate is statistically significant at the 10 percent, 5 percent or 1 percent level, respectively. Source: own elaboration.

\subsection{Marginal cost of public services and agricultural productivity}

Literature has revealed that public spending on drivers of agricultural growth such as infrastructural development and provision of basic amenities - access to good roads and primary health is sine qua non to agricultural development. Therefore, evaluating the requisite cost that would achieve this purpose is significant. To assess marginal returns of public spending on these indicators would require accessing information on the unit cost. Evaluating the financial implication of how much it would cost to educate 
the majority of Nigerians to attend at least primary school level entails assessing various channels that can facilitate attendance and knowledge impartation. These include provision of primary school institutions closer to the people, adequate teachers and motivation of teachers to provide quality teaching among others. Hence, the financial implication was estimated based on these criteria (Table 8).

Data were sourced from the Federal Ministry of Education, non-governmental agencies and other relevant sources. Average annual spending on public institutions was calculated and divided by the total number of pupils enrolled in the corresponding educational system. Thus, the estimated (on average) annual cost was computed. The result revealed $\mathrm{N} 12,550.00 /$ pupil/year $(\$ 34.86)$ for primary school pupils over the years under consideration. This was then multiplied by the number of people that completed at least primary education to arrive at the marginal cost (Table 8). The question arises: can this cost enhance human capital development? This is a matter to be discussed in future research. Data on access to health care were sourced through numerous outlets to estimate marginal cost using the methodology of Benin et al. (2009) that estimated the average unit cost from previous investments, where the accrued public capital stock is divided by total expenditure over several years. Due to data limitation, the study modified this approach. Firstly, data were sourced to calculate the average annual spending on provision of health facilities and second, access to health care services by most Nigerians. These steps enabled the study to source for data on the proportion of households living within 45 minutes of health-care facilities and that have access to moderate/quality health care. For example, access will improve when people themselves move closer to an existing facility or service or when they invest in ways to reach the facility for prompt service delivery.

Table 8. Marginal (one-percent increase in) stock and costs of public expenditures (1981-2018)

\begin{tabular}{|c|c|c|c|c|c|}
\hline \multirow{2}{*}{ Explanatory variables } & \multirow{2}{*}{$\begin{array}{l}\text { Total } \\
\text { sample }\end{array}$} & \multicolumn{4}{|c|}{ Agro-ecological zone } \\
\hline & & $\begin{array}{l}\text { Marginal } \\
\text { savanna }\end{array}$ & $\begin{array}{l}\text { Derived } \\
\text { savanna }\end{array}$ & $\begin{array}{l}\text { Rainforest } \\
\text { zone }\end{array}$ & $\begin{array}{l}\text { Mangrove/ } \\
\text { Swamp zone }\end{array}$ \\
\hline Education ( $\mathrm{A}$ billion) & 902.52 & 206.65 & 213.29 & 234.96 & 247.65 \\
\hline $\begin{array}{l}\text { Marginal stock (population completed } \\
\text { at least primary education) No in \% of } \\
\text { the population }\end{array}$ & 65.67 & 38.17 & 56.48 & 89.72 & 78.29 \\
\hline marginal cost (\%) ( $\mathrm{N}$ billion) & 12.30 & 3.04 & 3.25 & 2.49 & 1.83 \\
\hline Access to health care ( $\mathbb{N}$ billion) & 341.43 & 77.25 & 79.29 & 89.20 & 95.75 \\
\hline $\begin{array}{l}\text { Marginal stock (households within } 45 \\
\text { minutes' walk to health centre) No in } \%\end{array}$ & 36.74 & 28.16 & 33.28 & 47.26 & 38.26 \\
\hline marginal cost (\%) ( $\mathrm{N}$ billion) & 37.53 & 12.16 & 10.78 & 7.12 & 4.85 \\
\hline Access farm roads (N-Billion) & 48.49 & 13.45 & 12.61 & 11.78 & 10.05 \\
\hline $\begin{array}{l}\text { Marginal stock (farm access of } \mathrm{km} \text { per sq } \\
\mathrm{km} \text { ) No in } \%\end{array}$ & 62.77 & 81.06 & 72.92 & 58.36 & 38.72 \\
\hline marginal cost (\%) ( $\mathbb{N}$ billion) & 21.54 & 12.15 & 7.90 & 3.05 & 1.70 \\
\hline
\end{tabular}

Sources: www.epdc.org/Nigeria_coreusaid, www.ibe.unesco.org, www.nigerianstat.gov.ng/nada/index.php/catalog/27.

Following this deduction, the study sourced data and estimated the total number of households that resided within 45 minutes of a health facility and the number of people who visited these facilities for their health concerns. Thus, the total number of households were divided by the number of years under consideration to get the average annual change of the number of households existing within 45 minutes 
of a health centre. Therefore, the study estimated the average annual cost of providing public health services by the Federal Ministry of Health to be N68,006.00 (\$188.91) (study estimate), and divided by the number of households living within 45 minutes of a health facility. To get the marginal cost, the unit cost of one household member within 15-45 minutes' walk to a health facility to obtain quality health services was then multiplied by the number of people that accessed these facilities (Table 8).

Similarly, estimating the marginal stock (i.e. farm access of $\mathrm{km}$ per sq. $\mathrm{km}$ in \%) of people that have access to modest farm-roads was estimated by calculating how much it would cost to build one kilometre of rural road and the number of people that have access to these roads. To obtain the marginal cost concerning access to farm roads, total length of feeder roads was multiplied by the number of kilometres of road to farms and local markets and this outcome was used to obtain the marginal cost. Hence, the estimated unit cost of N23, 602.00 (\$65.56) (study estimate) was gotten (Table 8). These marginal costs are then divided by their respective marginal effects to obtain estimated marginal returns.

\subsection{Public investments and marginal agricultural productivity returns in Nigeria}

Table 9 presents marginal agricultural productivity returns on public spending while Tables 7 and 8 present estimates of marginal cost and the marginal effects that were used for the estimate.

Table 9. Marginal agricultural productivity returns to public investments in Nigeria

\begin{tabular}{lccccc} 
& & \multicolumn{3}{c}{ Agro-ecological zone } \\
\cline { 3 - 6 } Explanatory variables & $\begin{array}{c}\text { Total } \\
\text { sample }\end{array}$ & $\begin{array}{c}\text { Marginal } \\
\text { savanna }\end{array}$ & $\begin{array}{c}\text { Derived } \\
\text { savanna }\end{array}$ & $\begin{array}{c}\text { Rainforest } \\
\text { zone }\end{array}$ & $\begin{array}{c}\text { Mangrove/ } \\
\text { Swamp zone }\end{array}$ \\
\hline Agriculture & & $8.05^{* *}$ & $7.08^{* * *}$ & $5.92^{* *}$ & $2.05^{* *}$ \\
Education & $12.97^{* * *}$ & 1.91 & 1.34 & $0.82^{* * *}$ & 0.42 \\
Access to health care & $3.03^{* *}$ & $3.02^{* * *}$ & $2.61^{* * *}$ & $1.63^{* *}$ & $1.71^{*}$ \\
Access farm roads & $5.14^{* *}$ & $3.06^{* * *}$ & $2.91^{* * *}$ & $-2.35^{*}$ & -0.82 \\
\hline
\end{tabular}

Notes: See Table 1 for a detailed description of the variables. All continuous variables are transformed by natural logarithm, which is indicated by Ln. *, ** and ${ }^{* * *}$ means that the coefficient is statistically significant at the 10 percent, 5 percent or 1 percent level, respectively. Source: own elaboration.

Marginal effects were derived using Tables 4 and 5 as a guide and were presented in Table 7. The study computed the marginal cost by estimating the current population and then multiplied it with the unit cost (Table 8). Hence, marginal cost and marginal effects results were then used to assess the marginal agricultural productivity returns on the various types of public investment in the four agroecological zones (as displayed in equations 7 and 8). The results were presented in Table 9. The study revealed that significant amounts were extended to these indicators but returns were not commensurable (Table 9). For the years under consideration, the country had invested over N71.37 billion $(\$ 190 \mathrm{M})$, while the marginal Nigerian naira $(\mathrm{N})$ invested in the agricultural sector was $\mathrm{N} 12.97$ (\$0.036) as a margin of the total value of agricultural productivity returned. Surprisingly, drivers of agricultural productivity recorded low marginal Naira invested, (education N3.03, access to health care N5.14 and access to farm-roads N5.03). These results established a benefit-cost ratio of 4.4:1, meaning that increasing public spending on education, farm feeder roads and health care by $4.4 \%$ would enhance agricultural productivity by $1 \%$. Although these indicators are significant and positive, according to world indicators, they are very low. Results of the agricultural productivity returns from access to farm roads indicated a negative in the rainforest and mangrove swamp zones. These outcomes thus suggest 
that vegetation in these zones did not create a smooth access for agricultural activities. The assessed marginal returns on the various types of public investments vary among the four agro-ecological zones, the highest being the marginal and derived savannah zones, followed by the rainforest area (Table 9). Marginal returns on public spending on education are the highest, followed by the health sector and finally, access to farm roads.

\subsection{Policy implications of major findings}

Public spending on agriculture in Nigeria remains low regardless of the signs used. Allocation to agriculture from total public spending (annual budget) averaged 4.88 percent between 1981 and 2018. The marginal/short grass savannah agro-ecological zone received the most $(7.32 \%)$, while the mangrove/swamp agro-ecological area saw only 2.39\%. Budgetary allocation to agriculture compared with other key sectors was also low despite the sector's role in the fight against poverty, hunger, and unemployment and in the pursuit of economic development. Agricultural contribution to GDP (\%) from 1981-2018 averaged $32.70 \%$, while total funding (shares) to the agricultural sector also indicated $32.52 \%, 47.16 \%, 37.80 \%$ and $17.82 \%$ across the zones respectively. In this regard, intervention of local and foreign direct investments in public spending on agriculture showed $63.47 \%, 76.51 \%, 80.34$ and 74.69 in marginal/short grass savannah, derived/woodland long grass savannah, rainforest and mangrove/swamp agro-ecological areas respectively. This finding was supported by the studies of Mongues et al. (2008) and Benin \& Nin-Pratt (2015) which recognized the role local and foreign direct investment intervention agencies played in agricultural development in Nigeria and in Africa.

Evidence from other African countries revealed that public expenditure on agriculture in Ghana averaged 3.5-6.9\% in 1995-2005, in Kenya (6.5-7.5\%) and in Uganda (3-10\%). In Uganda, development/capital spending reliably accounts for around $15 \%$ of total sector spending, leaving $85 \%$ of the budget for recurrent costs. Hence international donor agencies have traditionally provided the majority of funding for development/capital operations in Uganda (Makhtar, 2017; Ministry of Foreign Affairs, 2005; Otsuka \& Hayami, 1988). Recurrent expenditure (personnel stipends and general administration) took 70-80\% in Ghana, and in Kenya, 69\%. Intervention funding (such as international donors) i.e., non-government funding in agriculture (both local and direct investment) in Ghana is between 59.1-73.5\% and in Kenya 62-83\% (Ministry of Foreign Affairs, 2005). Moreover, Asia, China, India and Thailand allocated $10-15 \%$ of the state budget to agriculture with capital expenditure accounting for $75 \%$ of spending; only $25 \%$ of the budget is for salaries, operations and maintenance. In the European Union public spending and related spending to agricultural development is between 43.5\% and 51.5\% (European Commission, 2016a, 2017, 2018). These countries witnessed higher returns on agricultural productivity. Proof from the regression results show the positive and significant role public spending played in agricultural productivity. This suggests the significant role quality public spending plays in agricultural growth.

The marginal effect of educational access in Nigeria was positive in the savannah zones, suggesting that people with higher education also work on the farms. This finding was supported by Quiroga et al. (2017) and Kostlivý et al. (2017). Access to quality health services holds universally true, hence, inclusive access to health services enhanced productivity. The study's result of the marginal effects (0.028) for access to farm roads was significant and positive indicating that a $1 \%$ increase in agricultural public spending on road development is related to an 0.028 increase in the value of agricultural production per capita. Meanwhile improved spending on health and rural roads independently could motivate better agricultural productivity. Hence, this study suggests that harmonizing along with quality spending on access to health, education and rural roads for the enhancement of agricultural productivity is paramount.

Annual budget allocation to education is the largest among all sectoral public spending in Asia: at $\$ 87$ per person, while in Europe it reaches \$115, and in South America \$45-52 per person (European Commission, 2017, 2018) whereas in sub-Saharan Africa (SSA) countries spent a meagre \$11per capita 
for education and $\$ 8$ for infrastructure from 2007 to 2013 (Ojiako et al., 2016). In Nigeria, the study indicated $\$ 8$ per person was spent to acquire a minimum education (at least primary education). Hence, public spending on the educational sector in Nigeria is low compared to other countries. In Asia, Europe, South America and other developed countries the educational sector received precedence in resource allocation, with about $16 \%$ of the government budget dedicated to educational related activities (Kostlivý et al., 2017; Quiroga et al., 2017), while in Nigeria less than 9\% is allocated to education, and less than $7 \%$ to health and roads during the years under review.

\section{Conclusions}

The study examined the effect of public spending on agricultural productivity in Nigeria (19812018). The results revealed that public spending on agriculture in Nigeria is poor by international standards and therefore limited agricultural productivity. Also, public spending on drivers of agricultural growth such as access to quality health care, education and farm feeder roads that can enhance agricultural productivity was poor throughout the years under review, hence, meagre agricultural productivity returns. Benin \& Nin-Pratt (2015), Benin (2015), Alene \& Coulibaly (2009), Fan et al. (2008) and Thirtle, Lin \& Piesse (2003) revealed evidence of agricultural productivity returns on quality public spending on agricultural sectors as well as on drivers of agricultural growth (access to health care facilities, education and farm feeder roads).

Consequently, quality public spending can be efficiently used to motivate agricultural growth and improve agricultural productivity. Nigerian governments need to increase public spending on agriculture and drivers of agricultural growth (farm feeder roads, education and healthcare.) The study revealed that in Nigeria, these drivers were not effectively motivated and were poorly funded. In addition, the low budget (less than 5\%) appropriated to agriculture during the reviewed years influenced poor agricultural productivity returns. Hence, the study recommends that governments should improve on the existing public spending in the agricultural sector and drivers of agricultural growth to improve agricultural productivity.

\section{References}

Alene, A. D., \& Coulibaly, O. (2009). The impact of agricultural research on productivity and poverty in Sub-Saharan Africa. Food Policy, 34(2) 198-209. DOI: https://doi.org/10.1016/i.foodpol.2008.10.014

Alshahrani, S. A., \& Alsadiq, A. J. (2014). Economic growth and government spending in Saudi Arabia: An empirical investigation. IMF Working Papers, WP/14/3. Washington, DC: International Monetary Fund. Retrieved from: https://www.imf.org/external/pubs/ft/wp/2014/wp1403.pdf

Amemiya, T. (1977). The maximum likelihood and the nonlinear three-stage least squares estimator in the general nonlinear simultaneous equation model. Econometrica, 45 (4), 955-968.

DOI: https://doi.org/10.2307/1912684

Anisimova, E. (2016). Public expenditure in agriculture: trends, "black boxes", and more. Washington, DC: International Food Policy Research Institute. Retrieved from: https://www.ifpri.org/blog/public-expenditureagriculture-trends-\%E2\%80\%9Cblack-boxes\%E2\%80\%9D-and-more

Ansari, M. I., Gordon, D. V., \& Akuamoah, C. (1997). Keynes versus Wagner: Public expenditure and national income for three African countries. Applied Economics, 29(4): 543-550.

DOI: https://doi.org/10.1080/000368497327038

Aregbeyeni, 0., \& Kolawole, B. 0. (2015). Oil revenue, public spending and economic growth relationships in Nigeria. Journal of Sustainable Development, 8(3), 114-123. D0I: https://doi.org/10.5539/jsd.v8n3p113

Arndt, C., Pauw, K., \& Thurlow, J. (2015). The economy-wide impacts and risks of Malawi's farm input subsidy program. American Journal of Agricultural Economics, 98(3), 962-980. DOI: https://doi.org/10.1093/ajae/aav048

Attari, M. I. J., \& Javed, A. Y. (2013). Inflation, economic growth and government expenditure of Pakistan: 19802010. Procedia Economics and Finance, 5, 58-67. DOI: https://doi.org/10.1016/S2212-5671(13)00010-5 
Babalola, A. I. (2015). Fiscal policy and economic development in Nigeria. Journal of Economic and Sustainable Development, 6(7), 150-160. Retrieved from: https://core.ac.uk/download/pdf/234646971.pdf

Babatunde, S. A. (2018). Government spending on infrastructure and economic growth in Nigeria. Economic Research-Ekonomska Istraživanja, 31(1), 997-1014. DOI: https://doi.org/10.1080/1331677X.2018.1436453

Baldos, U. L. C., Viens, F. G., Hertel, T. W., \& Fuglie, K. O. (2018). R\&D spending, knowledge capital, and agricultural productivity growth: A bayesian approach. American Journal of Agricultural Economics, 101(1), 291-310. DOI: https://doi.org/10.1093/ajae/aay039

Benin, S. (2015). Returns to agricultural public spending in Africa South of the Sahara. IFPRI Discussion Paper 01491. Washington, DC: International Food Policy Research Institute. Retrieved from: http://ebrary.ifpri.org/utils/getfile/collection/p15738coll2/id/129997/filename/130208.pdf

Benin, S., Mogues, T., Cudjoe, G., \& Randriamamonjy, J. (2009). Public expenditures and agricultural productivity growth in Ghana. 2009 Conference, August 16-22, 2009, Beijing, China. Milwaukee, WI: International Association of Agricultural Economists. DOI: https://doi.org/10.22004/ag.econ.51634

Benin, S., Mogues, T., Cudjoe, G.. \& Randriamamonjy. J. (2012). Public expenditures and agricultural productivity growth in Ghana. In T. Mogues \& S. Benin (Eds.), Public expenditures for agricultural and rural development in Africa. London, UK / New York, NY: Routledge, Taylor and Francis Group. Retrieved from: https://www.ifpri.org/publication/public-expenditures-agricultural-and-rural-development-africa

Benin, S., \& Nin-Pratt, A. (2015). Inter-temporal trends in agricultural productivity. In S. Benin (Ed.), Agricultural productivity in Africa: Inter-temporal trends, spatial patterns, and determinants. Washington, DC: International Food Policy Research Institute. Retrieved from: https://www.ifpri.org/publication/agricultural-productivity-africa-trends-patterns-and-determinants

Central Bank of Nigeria. (2016). Annual Statistical Bulletin. Garki Abuja, Nigeria: Central Bank of Nigeria. Retrieved from: https://www.cbn.gov.ng/documents/Statbulletin.asp

Chan, S., Ramly, Z., \& Abdkarim, M. (2017). Government spending efficiency on economic growth: Roles of valueadded tax. Perspectives on East Asian Economies and Industries,46(2), 162-188. DOI: https://doi.org/10.1080/1226508X.2017.1292857

Coelli, T. J. \& Prasada Rao, D. S. (2005). Total factor productivity growth in agriculture: A Malmquist index analysis of 93 countries, 1980-2000. Agricultural Economics, 32(1), 115-134.

DOI: https://doi.org/10.1111/j.0169-5150.2004.00018.x

De Olde, E. M., Sautier, M., \& Whitehead, J. (2018). Comprehensiveness or implementation: Challenges in translating farm-level sustainability assessments into action for sustainable development. Ecological Indicators, 85, 1107-1112. DOI: https://doi.org/10.1016/i.ecolind.2017.11.058

Dhrymes, P. J. (1973). Small sample and asymptotic relations between maximum likelihood and three stage least squares estimators. Econometrical, 41(2), 357-364. DOI: https://doi.org/10.2307/1913495

Diao, X., Fan, S., Kanyarukiga, B., \& Yu, B. (2010). Agricultural growth and investment options for poverty reduction in Rwanda. IFPRI Research Monograph. Washington, DC: International Food Policy Research Institute. DOI: http://dx.doi.org/10.2499/9780896291768

European Commission. (2016a). EU farm economics summary2013. EU Agricultural and Farm Economics Briefs, 14. Brussels, Belgium: European Commission. Retrieved from:

https://ec.europa.eu/info/sites/info/files/food-farming-fisheries/farming/documents/agri-farmeconomics-brief-14_en.pdf

European Commission. (2016b). Productivity in EU agriculture-slowly but steadily growing. EU Agric Market Briefs, 10. Brussels, Belgium: European Commission. Retrieved from: https://ec.europa.eu/info/sites/info/files/food-farming-fisheries/trade/documents/agri-market-brief10 en.pdf

European Commission. (2017). 2017 - EU agricultural markets short-term outlook reports. Brussels, Belgium: European Commission. Retrieved from:

https://ec.europa.eu/info/food-farming-fisheries/farming/facts-and-figures/markets/outlook/short-term

European Commission. (2018). 2018 - EU agricultural markets short-term outlook reports. Brussels, Belgium: European Commission. Retrieved from:

https://ec.europa.eu/info/food-farming-fisheries/farming/facts-and-figures/markets/outlook/short-term

Fan, S., Hazell, P., \& Thorat, S. (2000). Government spending, agricultural growth and poverty reduction in India. American Journal of African Economics, 5(4), 133-165.

Fan, S., Nyange, D., \& Rao, N. (2012). Public investment and poverty reduction in Tanzania: Evidence from household survey data. In In T. Mogues \& S. Benin (Eds.), Public expenditures for agricultural and rural development in Africa. London, UK / New York, NY: Routledge, Taylor and Francis Group. Retrieved from: https://www.ifpri.org/publication/public-expenditures-agricultural-and-rural-development-africa 
Fan, S., \& Zhang, X. (2008). Public expenditure, growth and poverty reduction in rural Uganda. African Development Review, 20(3), 466-496. DOI: https://doi.org/10.1111/j.1467-8268.2008.00194.x

Gallant, A. R., \& Dale, W. J. (1979). Statistical inference for a system of simultaneous, non-linear, implicit equations in the context of instrumental variable estimation. Journal of Econometrics, 11(2-3), 275-302. DOI: https://doi.org/10.1016/0304-4076(79)90041-1

Goyal, A., \& Nash, J. (2016). Reaping richer returns. Public spending priorities for African agriculture productivity growth. Washington, DC: World Bank. Retrieved from: https://openknowledge.worldbank.org/bitstream/handle/10986/25782/109330-WP-P153531-PUBLICENGLISH-WBReapingRicherReturnsfinalweb.pdf?sequence=1\&isAllowed=y

Greene, W. H. (1993). Econometric analysis. New York, NY: Macmillan.

Hsieh, E., \& Lai, K. (1994). Government spending and economic growth: The G-7 experience. Journal of Applied Economics, 26(5) 535-542. DOI: https://doi.org/10.1080/00036849400000022

Jorgenson, D. W., \& Laffont, J. J. (1975). Efficient estimation of nonlinear simultaneous equations with additive disturbances. Annals of Economic and Social Measurement, 3(4), 615-640.

Karamba, R. W., \& Winters, P. (2015). Gender and agricultural productivity: Implications of the farm input subsidy program in Malawi. Agricultural Economics, 46(3), 357-374.

DOI: https://doi.org/10.1111/agec.12169

Kareem, R. O., Bakare, H. A., Ademoyewa, G. R., Ologunla, S. E., \& Arije, A. R. (2015). Nexus between Federal Government spending on agriculture, agricultural output response and economic growth of Nigeria (1979-2013). American Journal of Business, Economics and Management, 3(6), 359-366.

Kostlivý, V., Fuksová, Z., \& Dubec, J. (2017). Farms productivity developments based on Malmquist Production Indices. Agris on-line Papers in Economics and Informatics, 9(2), 91-100.

DOI: https://doi.org/10.7160/aol.2017.090208

Makhtar, D. (2017). Efficiency of public spending will enhance agriculture productivity for poverty reduction in Africa. Washington, DC: World Bank.

Manyong, V. M., Ikpi, A., Olayemi, J. K., Yusuf, S. A., Omona, B. T., Okoruwa, V., \& Idachaba, F. S. (2005). Agriculture in Nigeria: Identifying opportunities for increased commercialization and investment. Ibadan, Nigeria: International Institute of Tropical Agriculture (IITA). Retrieved from:

https://books.google.es/books?id=UAzSiaumx1AC\&printsec=frontcover\&hl=es\&source=gbs ge summary r\& $\mathrm{cad}=0 \# \mathrm{v}=$ onepage $\& \mathrm{q} \& \mathrm{f}=$ false

Ministry of Foreign Affairs. (2005). A joint evaluation of Uganda's Plan for the modernization of agriculture. Koege, Denmark: Ministry of Foreign Affairs, Evaluation Department.

Retrieved from: http://www.oecd.org/countries/uganda/35992588.pdf

Mogues, T., Fan, S., \& Benin, S. (2015). Public investments in and for agriculture. European Journal of Development Research, 27(3), 337-352.

Mogues, T., Morris, M., Freinkman, L., Adubi, A., Ehui, S. (2008). Agricultural public spending in Nigeria. IFPRI Discussion Paper 00789. Washington, DC: International Food Policy Research Institute. Retrieved from: http://ebrary.ifpri.org/utils/getfile/collection/p15738coll2/id/13561/filename/13562.pdf

Ojiako, F., Chianu, F., Johm, K., \& Ojukwu, C. (2016). Drivers of human capital development: An analysis of primary and secondary education outcomes in Nigeria. International Journal of Current Research, 8(6), 32285-32297. Retrieved from: https://www.journalcra.com/sites/default/files/issue-pdf/14852.pdf

Otsuka, K., \& Hayami, Y. (1988). Theories of share tenancy: A critical survey. Economic Development and Cultural Change, 37 (1), 31-68. Retrieved from: https://www.jstor.org/stable/1154179?seq=1

Oyenuga, V. A. (1967). Agriculture in Nigeria. Rome, Italy: Food and Agriculture Organization of the United Nations.

Peón Pose, D., Martínez-Filgueira, X. M., \& López-Iglesias, E. (2020). Productive vs. residential economy: Factors behind the recovery of rural areas in socioeconomic decline. Revista Galega de Economía, 29(2), 1-30. DOI: https://doi.org/10.15304/rge.29.2.6744

Petkovová, L., Hartman , D., \& Pavelka, T. (2020). Problems of aggregation of sustainable development indicators at the regional level. Sustainability, 12(17), 7156. DOI: https://doi.org/10.3390/su12177156

Quiroga, S., Suárez, C., Fernández-Haddad, Z., \& Philippidis, G. (2017). Levelling the playing field for European Union agriculture: Does the Common Agricultural Policy impact homogeneously on farm productivity and efficiency?, Land Use Policy, 68, 179-188. DOI: https://doi.org/10.1016/j.landusepol.2017.07.057

Rodrik, D. (2016). Premature deindustrialisation. Journal of Economic Growth, 21(1), 1-33. DOI: https://doi.org/10.1007/s10887-015-9122-3

Rural Business Research. (2016). Farm Business Survey. Cambdrige, UK: University of Cambridge. Retrieved from: http://www.farmbusinesssurvey.co.uk/index.aspx 
Siebrecht, N. (2020). Sustainable agriculture and its implementation gap-Overcoming obstacles to implementation. Sustainability, 12 (11), 3853. DOI: https://doi.org/10.3390/su12093853

Sowunmi, F. A., \& Akintola, J. O. (2010). Effect of climatic variability on maize production in Nigeria. Research Journal of Environmental and Earth Sciences, 2(1), 19-30.

Retrieved from: https://maxwellsci.com/print/rjees/v2-19-30.pdf

Svilokos, T., Vojinić, P., \& Tolić, M. S. (2019). The role of the financial sector in the process of industrialisation in Central and Eastern European countries. Economic Research-Ekonomska Istraživanja, 32(1), 384-402.

DOI: https://doi.org/10.1080/1331677X.2018.1523739

Takeshima, H., \& Liverpool-Tasie, L. (2015). Fertilizer subsidies, political influence, and local food prices in SubSaharan Africa: Evidence from Nigeria. Food Policy, 54, 11-24. DOI: https://doi.org/10.1016/j.foodpol.2015.04.003

Tenaye, A. (2020). Sources of productivity growth in Ethiopian agriculture. African Journal of Agricultural Research, 15(1), 19-32. DOI: https://doi.org/10.5897/AJAR2019.14601

Thirtle, C., Lin, L., \& Piesse, J. (2003). The impact of research-led agricultural productivity growth on poverty reduction in Africa, Asia, and Latin America. World Development, 31(12), 1959-1975. DOI: https://doi.org/10.1016/j.worlddev.2003.07.001

Wu, S.-Y., Tang, J.-H., \& Lin, E. S. (2010). The impact of government expenditure on economic growth: How sensitive to the level of development? Journal of Policy Modeling, 32(6), 34-45. DOI: https://doi.org/10.1016/j.jpolmod.2010.05.011

Zhang, X., \& Fan, S. (2004). Public investment and regional inequality in rural China. Agricultural Economics, 30(2), 89-100. DOI: https://doi.org/10.1016/j.agecon.2002.09.003 